\title{
INVESTIGACIÓN
}

\section{Influence of the extraction procedure on the antioxidative activity of lentil seed extracts in a $\beta$-carotene-linoleate model system}

\author{
By R. Amarowicz ${ }^{\mathrm{a}}$, M. Karamac ${ }^{\mathrm{a}}$ and U. Chavan ${ }^{\mathrm{b}}$ \\ ${ }^{a}$ Division of Food Science, Institute of Animal Reproduction and Food Research of \\ Polish Academy of Sciences, ul. Tuwima 10, P.O. Box 55,10-718 Olsztyn, Poland \\ ${ }^{\mathrm{b}}$ Department of Biochemistry, Mahatma Phule Agriculture University, Rahuri, India
}

\begin{abstract}
RESUMEN
Influencia del procedimiento de extracción en la actividad antioxidante de extractos de semilla de lenteja en un sistema modelo $\beta$-caroteno linoleato

Los compuestos fenólicos fueron extraídos de semillas de lenteja usando tres sistemas de disolventes: acetona del $80 \%$ $(\mathrm{v} / \mathrm{v})$, metanol del $80 \%(\mathrm{v} / \mathrm{v})$, y etanol del $80 \%(\mathrm{v} / \mathrm{v})$. Cada extracto fue separado posteriormente en dos fracciones por cromatografía en columna con Toyo Pearl HW-40 usando agua (fracción I) y metanol (fracción II) para la elución. La actividad antioxidante de los extractos y de sus fracciones respectivas fueron examinadas en un sistema modelo $\beta$-caroteno-linoleato. Los tres extractos exhibieron actividad antioxidante similar. Atendiendo al nivel de compuestos fenólicos en los extractos parece que los compuestos del extracto acetónico eran menos activos que los metanólicos y etanólicos. Debido a que el contenido de fenoles era aproximadamente 16 veces más bajo en la fracción I de los extractos metanólico y etanólico comparado con la fracción II, los fenoles en la fracción I de los extractos del metanol y del etanol de las semillas de lenteja son mucho más activos que éstos en la fracción II.

Una actividad antioxidante más fuerte de la fracción I del extracto acetónico comparado con el extracto acetónico crudo fue observada durante el posterior periodo de incubación. La razón fué el relativamente alto nivel de compuestos fenólicos en esta fracción. El espectro UV confirmó que los compuestos fenólicos del extracto de acetona fueron diferentes comparados con los extractos metanólicos y etanólicos.
\end{abstract}

PALABRAS-CLAVE: Actividad antioxidante - $\beta$-caroteno linoleato - Extracción - Semilla de lenteja (extracto).

\section{SUMMARY}

Influence of the extraction procedure on the antioxidative activity of lentil seed extracts in a $\beta$-carotene-linoleate model system.

Phenolic compounds were extracted from lentil seeds using three solvent systems: $80 \%(\mathrm{v} / \mathrm{v})$ acetone, $80 \%(\mathrm{v} / \mathrm{v})$ methanol, and $80 \%(\mathrm{v} / \mathrm{v})$ ethanol. Each extract was subsequently separated into two fractions by chromatoghraphy on a column with Toyo Pearl HW-40 using water (fraction I) and methanol (fraction II) for elution. Antioxidative activity of extracts and their respective fractions were examined in a $\beta$-carotene-linoleate model system. All three extracts exhibited similar antioxidant activity. Considering the level of phenolic compounds in extracts it seems that phenolic compounds from the acetone extract were less active than those from either the methanolic and ethanolic ones. Because the content of phenolics was about 16 -fold lower in fraction I of the methanolic and ethanolic extracts compared to fraction II, the phenolics in fraction I of the methanol and ethanol extracts from lentil seeds are much more active than these in fraction II. A stronger antioxidant activity of fraction I from the acetone extract compared to the crude acetone extract was observed during the latter incubation stage. The reason was a relatively high level of phenolic compounds in this fraction. UV spectra confirmed that the phenolic compounds from the acetone extract were different compared to methanolic and ethanolic extracts.

KEY-WORDS: Antioxidative activity - $\beta$-carotene linoleate Extraction - Lentil seed (extract).

\section{INTRODUCTION}

Plant phenolics encompass a wide variety of compounds characterized by the presence of an aromatic ring with one or more hydroxyl groups and a variety of substituents. Many phenolic compounds are primary antioxidants as they act as free radical receptors and chain breakers (Shahidi and Wanasundara, 1992 ). Few publications deal with the antioxidant properties of phenolic compounds of legumes. However, Tsuda et al. (1993) reported antioxidant activity of phenolic compounds in a bean (Phaseolus vulgaris) extract. The results of a B-carotene-linoleate test indicated that the extracts from pea, faba bean, lentil, everlasting pea, and broad bean seeds had a similar antioxidative activity whereas extract from white bean seeds was slearly less active (Amarowicz et al., 1996b). The navy bean (Phaseolus vulgaris) hull extract was found to possess better antioxidant efficacy than a mixture of $\mathrm{BHA}-\mathrm{BHT}$ when used at the same concentration (Onyeneho and Hettiarachchy, 1991). Antioxidant properties were reported for the phenolic fractions separated using Sephadex LH-20 column chromatography from the extracts of everlasting pea (Lathyrus latifolius), faba bean (Vicia faba minor) and broad bean (Vicia faba maior) (Amarowicz et al., 1996c). Antioxidative activities of quercetin and kaempferol as well as their glucuronides and 
rutinosides, characterized as the main flavonoids of yellow and green beans (Phaseolus vulgaris), were evaluated by an enhanced chemiluminescence (ECL) technique (Raab et al., 1996; Hempel and Bohm, 1996). Hydrophilic oxygen radical scavengers in leguminous seeds were investigated by an EPR spin traping method (Yoshiki et al., 1996).

The aim of present study was to examine the antioxidant activity of a lentil seed extracts from different solvent systems and their respective fractions in a $\beta$-carotene-linoleate model system, as a first step for their evaluations in their potentil use in lipid containg foods as a substitute for synthetic antioxidants.

\section{MATERIALS AND METHODS}

Materials investigated were seeds of lentil (Lens culinaris) obtained from the Institute of Plant Genetics and Breeding of the Agricultural University in Lublin, Poland.

Defatted milled seeds were extracted twice with $80 \%(\mathrm{v} / \mathrm{v})$ acetone, $80 \%(\mathrm{v} / \mathrm{v})$ methanol and $80 \%$ $(\mathrm{v} / \mathrm{v})$ ethanol for $15 \mathrm{~min}$ at $80^{\circ} \mathrm{C}$ (Amarowicz et al., 1995a).

Following evaporation of the organic solvents in a rotary evaporator at $45^{\circ} \mathrm{C}$ the remaining aqueous solution was lyophilized.

A portion of the extract $(1 \mathrm{~g})$ was dissolved in 10 $\mathrm{ml}$ of methanol and then applied onto a Toyo Pearl HW-40 column $(40 \times 2.5 \mathrm{~cm})$. Water followed by methanol were used to wash the column. The water eluate (fraction I) was lyophylized and the methanol eluate (fraction II) was evaporated to dryness.

The content of phenolic compounds in the extract and fractions was determined using the Folin Ciocalteau reagent ( Naczk and Shahidi 1989 ) and (+)-catechin was used as a standard. UV spectra of the crude extract and fractions were recorded using a Beckman DU 7500 diode array spectrophotometer.

Antioxidative activity of the crude extract and its two fractions, separated by column chromatography, was determined by measuring the coupled oxidation of $\beta$-carotene and linoleic acid (Miller 1971). This method is simply and was used by many authors for evaluation of the antioxidant activity of phenolic compounds extracted from natural plant sources. Using Miller's test also synthetic antioxidants BHA, BHT and TBHQ were tested (Karamac and Amarowicz 1995). About $2 \mathrm{mg}$ of B-carotene was dissolved in $10 \mathrm{ml}$ of chloroform and $2 \mathrm{ml}$ of this solution was pipetted into a round-bottom flask. After removing the chloroform with a rotary evaporator, $20 \mathrm{mg}$ of linoleic acid, $200 \mathrm{mg}$ of Tween 40 and $50 \mathrm{ml}$ of oxygenated distilled were added to the flask with vigorous stirring. Aliqouts $(5 \mathrm{ml})$ of the prepared emulsion were transferred to a series of tubes containing either $2 \mathrm{mg}$ of extract or fraction I and $0.5 \mathrm{mg}$ of fraction II or the synthetic antioxidant (BHA). As soon as the emulsion was added to each tube, absorbance readings at $470 \mathrm{~nm}$ were recorded at 15 min intervals while keeping the samples in a water bath at $50^{\circ} \mathrm{C}$ for $120 \mathrm{~min}$.

\section{RESULTS AND DISCUSSION}

The content of total phenolic compounds in lentil seed extracts depended upon the solvent employed (Fig. 1). The acetone extract contained more phenolics $(22.6 \mathrm{~g} / 100 \mathrm{~g}$ of extract) than either methanol $(7.2 \mathrm{~g} / 100 \mathrm{~g}$ of extract) or ethanol (8.2 $\mathrm{g} / 100 \mathrm{~g}$ of extract) extracts. Fractions I of the methanol and ethanol extracts eluted from the Toyo Pearl HW-40 column contained small amounts of phenolics ( i.e., respectively 1.29 and $1.05 \mathrm{~g} / 100 \mathrm{~g}$ ) whereas Fraction I of the acetone extract contained substantially more phenolics (i.e. $6.06 \mathrm{~g} / 100 \mathrm{~g}$ of fraction I). Fraction II obtained from the acetone, methanol and ethanol extracts contained 19.7, 18.7, and $18.8 \mathrm{~g}$ phenolics $/ 100 \mathrm{~g}$ of fraction II, respectively.

Different phenolic compounds were present in the extracts so obtained as confirmed by UV spectroscopy. UV spectra of the crude extract from acetone showed a maximum at $275 \mathrm{~nm}$ (Fig. 2). Absorption maxima for UV spectra of the methanolic and ethanolic extracts were noted at a shorter wavelength of $271 \mathrm{~nm}$. All extracts exhibited a shoulder at $280 \mathrm{~nm}$ which are characteristic of catechins or procyanidins (Amarowicz and Shahidi, 1996). The presence of catechins and procyanidins in lentil extracts was detected using thin layer chromatography by Amarowicz et al (1995a) and by high performance liquid chromatography by Bartolome et al. (1994). High absorbance for extracts in the $310-320 \mathrm{~nm}$ region was most probably due to the presence of phenolic acids (Naczk et al., 1992). Phenolic acids such as protocatechuic, $p$-hydroxybenzoic, vanillic,

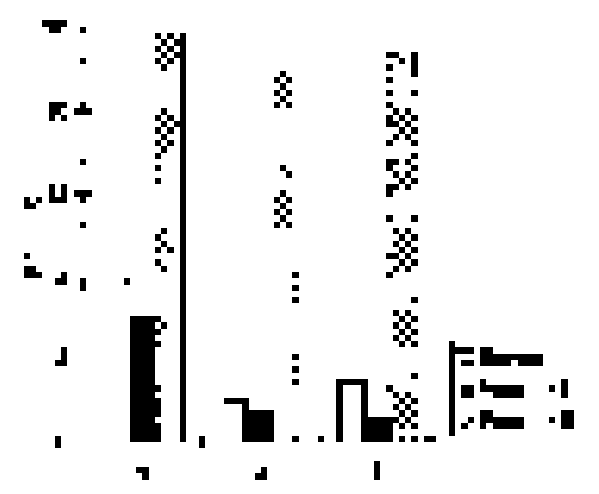

Figure 1

Content of phenolic compounds in crude extracts from lentil seeds and their fractions; extracts were obtained using $80 \%$ $(\mathrm{v} / \mathrm{v})$ solution of acetone (1), methanol (2) and ethanol (3) 
$p$-hydroxyphenylpropionic, gentisic, ferulic and $p$-hydroxycinnamic acid were found for lentil seeds (Bartolome et al., 1994). Some differences in the UV spectra of fractions I are presented in Fig.3. Fraction I with contained hydrophilic phenolic compounds separated from the methanolic and ethanolic extracts showed a maximum at $266 \mathrm{~nm}$ whereas the maximum in the spectrum of fraction I from the acetone extract was shifted slightly to $270 \mathrm{~nm}$. UV spectrum of fraction II from the acetone extract was characterized by a maximum at $282 \mathrm{~nm}$ whereas for fractions II from the both methanolic and ethanolic extracts, maxima were observed at $270 \mathrm{~nm}$ (Fig. 4) ; an additional shoulder at $282 \mathrm{~nm}$ was recorded for this fraction. Different UV spectra recorded for the acetone extract resulted from acetone's greater ability to extract tannins from the lentil seeds. Previously this observation had been confirmed by Amarowicz et al. (1995a) by TLC on silica gel.

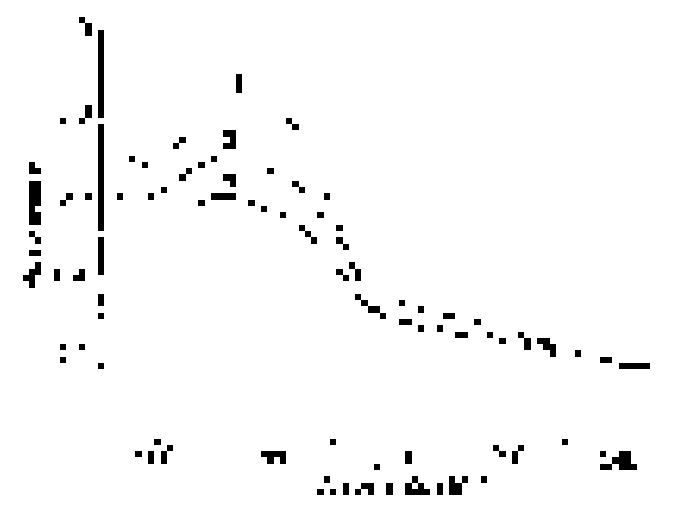

Figure 2

UV spectra of crude extracts from lentil seeds and their fractions; extracts were obtained using $80 \%(\mathrm{v} / \mathrm{v})$ solution of acetone (1), methanol (2) and ethanol (3)

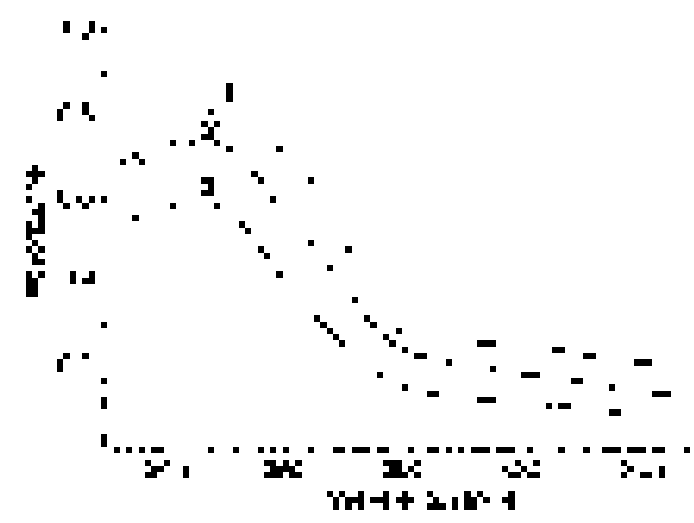

Figure 3

UV spectra of fractions I separated from crude extracts; extracts were obtained using $80 \%(\mathrm{v} / \mathrm{v})$ solution of acetone (1), methanol

(2) and ethanol (3)

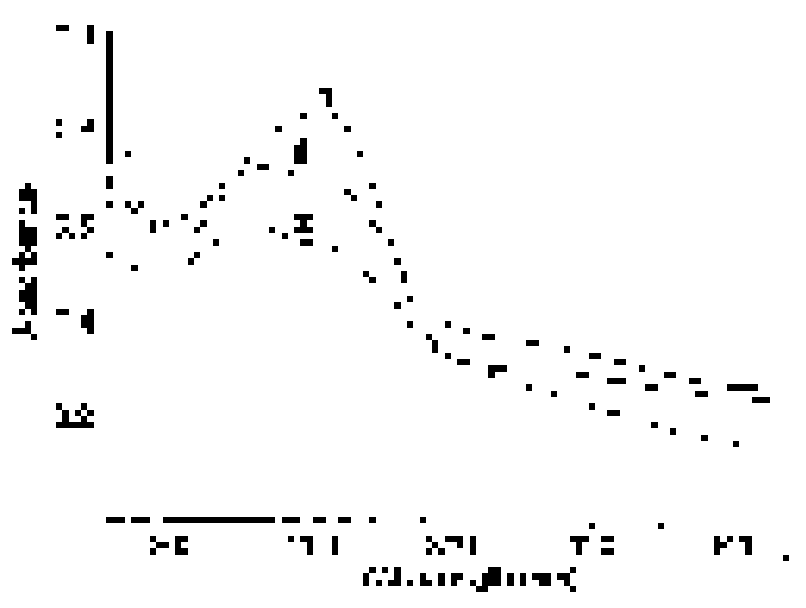

Figure 4

UV spectra of fractions II separated from crude extracts; extracts were obtained using $80 \%(\mathrm{v} / \mathrm{v})$ solution of acetone (1), methanol (2) and ethanol (3)

Results of the test with $\beta$-carotene and linoleic acid are presented as diagrams in Figs 5-7 All three extracts exhibited similar antioxidant activity. After 120 min of incubation absorbance for extract-treated systems was ca. 0.5 while that for the control sample (without extract) almost the zero. Considering the level of phenolic compounds in extracts it seems that phenolic compounds from the acetone extract were less active than those from either the methanolic and ethanolic ones. Because the content of phenolics was about 16-fold lower in fraction $I$ of the methanolic and ethanolic extracts compared to fraction II, the phenolics in fraction I of the methanol and ethanol extracts from lentil seeds are much more active than these in fraction II. A stronger antioxidant activity of fraction I from the acetone extract compared to the crude acetone extract was observed during the latter incubation stage (Fig.5). The reason was a relatively hing level of phenolic compounds in this fraction.

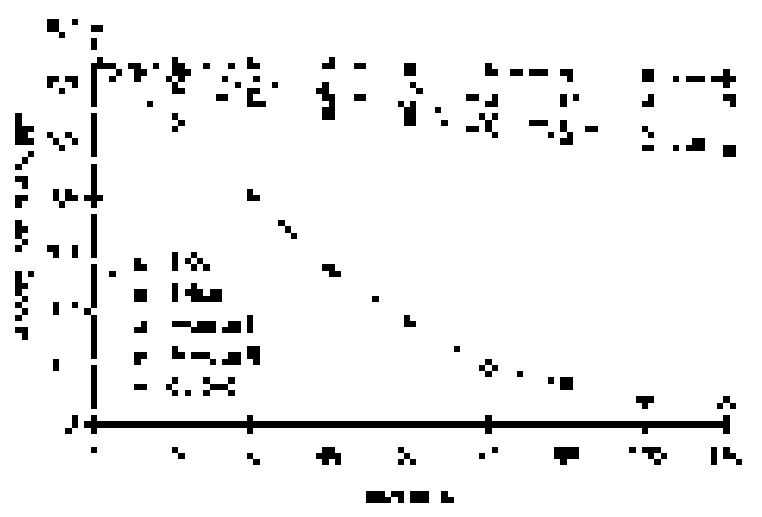

Figure 5

Antioxidative activity of acetone extract from lentil seeds and its two fractions 


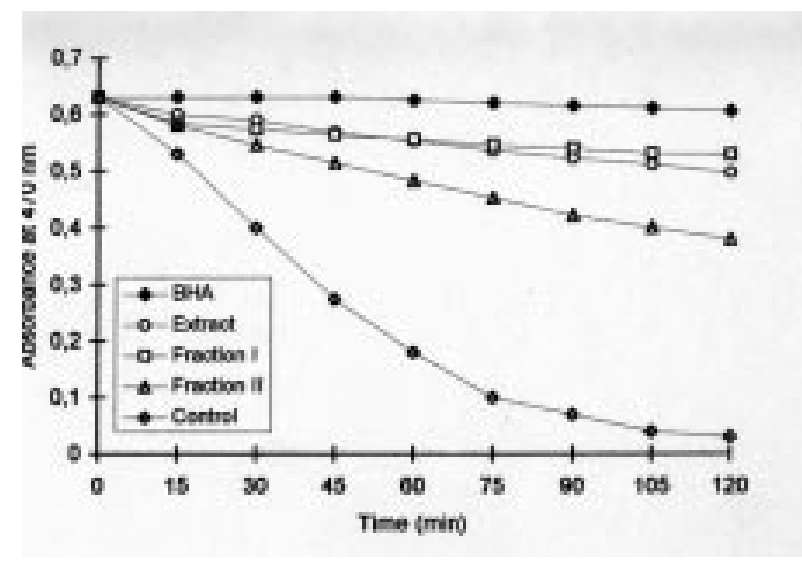

Figure 6

Antioxidative activity of methanol extract from lentil seeds and its two fractions

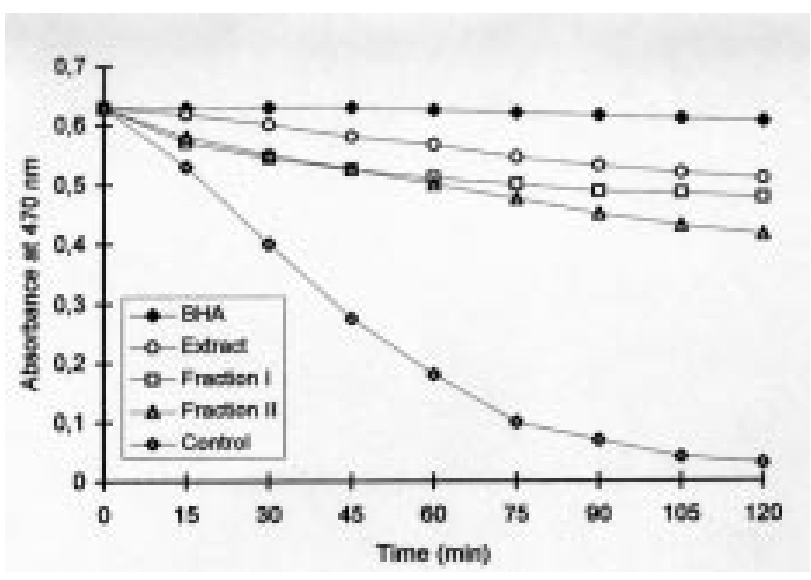

Figure 7

Antioxidative activity of ethanol extract from lentil seeds and its two fractions

Antioxidative properties of extracts from lentil seeds, especially for fractions eluted with water from the Toyo Pearl HW-40 column, can be regarded as very high.

They are comparable to the activity of extracts of green tea (Amarowicz and Shahidi 1995) and rapeseed (Amarowicz et al., 1995b), and with phenolics fractions from canola (Wanasundara et al., 1994), white mustard (Amarowicz et al., 1996a) and flax (Amarowicz et al., 1993; Amarowicz et al., 1997). Antioxidative activity of lentil seed extract evaluated by chemiluminescence methods was reported by Amarowicz and Raab (1997). Antioxidant activity evaluated by the enhanced chemiluminescence technique was $1772 \mathrm{nmol}$ Trolox/mg total phenolics in extract. For the photochemi luminescence method, activities measured were $2904 \mathrm{nmol}$ ascorbic acid/mg total phenolics in extract and 3965 $\mathrm{nmol}$ Trolox/mg total phenolics in extract. Polyphenolic compounds in the lentil seed coat possessed antioxidative activity measured using a liposome method (Troszynska et al. 1997). A stronger antioxidative activity observed for the hydrophilic fractions (the fractions I) is in accordance with results of the present investigation and to those of Tsuda et al. (1993). Tsuda et al. (1993) noted a strong antioxidant activity for the hydrophilic phenolic extract of bean (Phaseolus vulgaris) while the hydrophobic fraction showed only a weak one.

\section{REFERENCES}

Amarowicz, R., Wanasundara, U., Wanasundara, J. and Shahidi, F. (1993). Antioxidant activity of ethanolic extracts of flaxseed in a $\beta$-carotene-linoleate model system. J.Food Lipids 1, 111-117.

Amarowicz, R. and Shahidi, F.(1995). Antioxidant activity of green tea catechins in a B-carotene-linoleate model system. J. Food Lipids 2, 47-55.

Amarowicz, R., Piskula, M., Honke, J., Rudnicka, B., Troszynska, A. and Kozlowska, H. (1995a). Extraction of phenolic compounds from lentil (Lens culinaris) with various solvents. Pol. J. Food Nutr. Sci. 4/45, 53-62.

Amarowicz, R., Fornal, J. and Karamac, M. (1995b). Effect of seed moisture on phenolic acids in rapeseed oil cake. Grasas y Aceites 46, 354-356.

Amarowicz, R. and Shahidi, F. (1996). A rapid chromatographic method for separation of individual catechins from green tea. Food Res. Intern. 29, 71-76.

Amarowicz, R., Wanasundara, U., Karamac, M. and Shahidi, F. (1996a). Antioxidant activity of ethanolic extract of mustard seed. Nahrung 40, 261-263.

Amarowicz, R., Karamac, M., Troszynska, A. and Kozlowska, H. (1996b). Antioxidative properties of legume seed extracts in Agri-Food Quality. An Interdisciplinary Approach, p. 376-379. G. R. Fenwick, C. Hedley, R. L. Richards and S. Khokhar (Eds). The Royal Society of Chemistry, Cambridge.

Amarowicz, R., Karamac, M., Kmita-Glazewska, H., Troszynska, A. and Kozlowska, H. (1996c). Antioxidant activity of phenolic fractions of everlasting pea, faba bean and broad bean. J. Food Lipids 3, 199-211.

Amarowicz, R. and Raab, B. (1997). Antioxidative activity of leguminous seed extracts evaluated by chemiluminescence methods. Z. Naturforsch.C 52c, 709-712.

Amarowicz, R., Karamac, M., Wanasundara, J. and Shahidi, F. (1997). Antioxidant activity of hydrophobic phenolic fractions of flaxseed. Nahrung 41, 178-180.

Bartolome, B., Hernández, T. and Estrella, I. (1994). Procyanidins in lentils. Chenges produced by different treatment in Polyphenols 94. $17^{\text {th }}$ International Conference on Polyphenols, pp.267-268. R. Brouillard, M. Jay and A. Scalbert (Eds). INRA, Paris.

Hempel, J. and Bohm, H. (1996). Quality and quantity of prevailing flavonoids of yellow and green French beans (Phaseolus vulgaris L.). J. Agric. Food Chem. 44, 2114-2116.

Karamac, M. and Amarowicz, R. (1995). Antioxidant activity of BHA, BHT and TBHQ examined with Miller's test. Grasas y Aceites 48, 83-86.

Miller, H. E. (1971). -A simplified method for the evaluation of antioxidants. J. Am. Oil Che. Soc. 45,91.

Naczk, M. and Shahidi, F. (1989). The effect of methanol-ammonia-water treatment on the content of phenolic acids of canola. Food Chem. 31, 159-164. 
Naczk, M., Wanasundara, J. and Shahidi, F. (1992). Facile spectrotophotometric quantification method of sinapic acid in hexane-extracted and methanolammonia-water treated mustard and rapeseed meals. J. Agric. Food Chem. 40, 444-448.

Onyeneho, S.N. and Hettiarachy, N.S. (1991). Effect of navy bean hull extract on the oxidative stability of soy and sunflower oils. J. Agric. Food Chem. 39,1701-1704.

Raab, B., Hempel, J. and Bohm, H. (1996). Antioxidative and antigenotoxic properties of flavonoids prevaling in vegetable in Agri-Food Quality. An Interdisciplinary Approach, p. 369-371. G.R. Fenwick, C. Hedley, R.L. Richards and S. Khokhar (Eds). The Royal Society of Chemistry, Cammbridge.

Shahidi, F. and Wanasundara, P.K.J.P.D. (1992). Phenolic antioxidants. CRC Crit. Rev. Food Sci. Nutr. 32, 67-103.

Troszynska, A., Bednarska, A., Latosz, A. and Kozlowswka, H. (1997). Polyphenolic compounds in the seed coat of legume seeds. Pol. J. Food Nutr. Sci. 6, 37-45.

Tsuda, T., Osawa, T., Nakayama, T., Kawakishi, S. and Osawa, T. (1993). Antioxidant activity of pea bean (Phaseolus vulgaris L.) . J. Am. Oil Chem. Soc. 70, 909-913.

Wanasundara, U., Amarowicz, R. and Shahidi, F. (1994). Isolation and identification of an antioxidative component in canola meal. J. Agric. Food Chem. 42,1285-1290.

Yoshiki, Y., Sirakura, T., Okuda, K, Okubo, O, K., Sakabe, T., Nagoya, I. and Tamura, N. (1996). Hydrophilic oxygen radical scavengers in the leguminous seeds and derived foods in Agri-Food Quality. An Interdisciplinary Approach, p. 360-365. G.R. Fenwick, C. Hedley, R.L. Richards and S. Khokhar (Eds). The Royal Society of Chemistry, Cambridge. 